\title{
DOCUMENTATION OF RARE AND ENDANGERED ORNAMENTAL FLORA IN FOREST RESERVES OF GARO HILLS, MEGHALAYA
}

\author{
L. B. SANGMA* \& A. K. CHAURASIYA \\ Department of Horticulture, NEHU, Tura Campus
}

\section{ABSTRACT}

In the present investigation, a total number of 17 rare or endangered plant species have been recorded. The study of plant species highlights all the 17 rare or endangered plant species with their botanical names, family, habit and present scenario in all the districts of Garo Hills. Out of the 17 plant species, there was 5 plant species belonging to the family group of Droseraceae, Asclepiadaceae, Orchidaceae and Carryophyllaceae that have been listed in endangered category which requires an immediate attention for the conservation strategies. Many of the rare or endangered plants species can be found abundantly in the forest reserves of Nokrek National Park and Balpakram National Park area with a threatening situation. The best conservation area of the plant biodiversity was observed in the forest reserves such as the national parks, sanctuaries, biosphere reserves and sacred groves.

KEYWORDS: Rare, Endangered, Plants, National parks, Garo Hills, Forest, Meghalaya

Received: Dec 19, 2020; Accepted: Jan 09, 2021; Published: Feb 10, 2021; Paper Id.: IJBRJUN20214

\section{INTRODUCTION}

Meghalaya is among the few States in the country which can be proud of its abundance of natural forest wealth spanning across large part of its geographical area, much higher than national average. Its location, physiographical features, altitudinal variation, abundant rainfall, salubrious climate and fertile soils favours high species diversity and supports different types of forests. This rich flora had been the centre of attraction for many botanists starting from Buchanan Hamilton (1820-24) and rightly considered as 'Botanist Paradises'. This region was described by Hooker as "Cradle of Angiosperms". The undulating hilly terrain, where the plateau is dissected by rain-fed rivers, streams and deep ravines, waterfalls and hills covered with rich vegetation present picturesque landscape. The forests are also home to rare and endemic plants and animals. The undisturbed primary forests are botanically well known and extraordinarily rich. The forests of the state shelters more than 3500 flowering plants, 352 orchids, 40 bamboo species and about 800 medicinal plants resources. There are about 40 endemic plant species and 75 Threatened plant species found in Meghalaya. Amongst its rare species are the insect eating Pitcher plant (Nepenthes khasiana Hook f.), Wild citrus (Citrus indica Yu. Tanaka) and Pygmy Lily (Nymphaea tetragona L.).

\section{MATERIALS AND METHODS}

\section{STUDY AREA}

Meghalaya lies between 20.1 N' - $26.5 \mathrm{~N}^{\prime}$ latitude and 85.49 $\mathrm{E}^{\prime}-92.52 \mathrm{E}^{\prime}$ longitude and it is known for its rich diversity of flora and fauna. The name Meghalaya means 'the abode of clouds' in Sanskrit and the state capital, Shillong is also known as the Scotland of the East. In Asia, the sub-tropical forest area of Meghalaya has been considered as one of the richest in botanical habitats. Since the climatic and topographic conditions are diverse in the forest 
reserves of Garo hills, a vast floral diversity can be found in this region.

Garo Hills is situated in the western part of the state. The population is mainly dominated by the Garo tribe. Garo Hills usually receives extremely high rainfall and it has a very dense forest area cover. The average rainfall received annually is around $330 \mathrm{~cm}$ during the monsoon and the winter season is usually dry. The climatic condition in Garo Hills is majorly controlled by South-West monsoon winds and a fairly high temperature during summers. Garo Hills has two national parks, namely, Nokrek National Park and Balpakram National Park. Nokrek National Park is located in the western part of the state, whereas, Balpakram National Park lies on the southern part of the district. These National Parks protects a highly diverse flora and fauna that has been endangered due to over exploitation. The mountain peaks that are located in Garo Hills are called Tura Peak, Nokrek Peak, Meminram Peak, Nengminjok Peak, Chitmang Peak, Ranggira peak and Arbella peak. Nokrek peak is the highest point in Garo Hills with an elevation of 1412 meters above the sea level. Nokrek National Park is a home to the Indian wild orange (Citrus indica), which is the progenitor of citrus fruits. Balpakram National Park is known for its diverse wild animals and rich flora. Rare and endangered plant species namely, Drosera, pitcher plants and orchids can be found in this park.

\section{METHODOLOGY}

The present research was based on an extensive survey and observations of wild rare and endangered ornamental plants in different forest reserves of Garo Hills, Meghalaya during the year 2017-2019. In this investigation, diversity of rare and endangered wild ornamental flowering plants, which are distributed in the Garo Hills districts of Meghalaya were recorded. During the survey, the plant specimens were collected and preserved to prepare herbarium specimens. The collected specimens were identified taxonomically with the help of available floras and literature (Gamble \& Fischer 1935, Pullaiah et al., 1997, Reddy, et al., 2008) and by Department of Botany, NEHU . The specimens were processed for the preparation of Herbarium by standard methods (Santapau, 1973).

\section{STATUS OF RARE AND ENDANGERED WILD ORNAMENTAL FLORA OF GARO HILLS, MEGHALAYA}

Some rare and endemic ornamental plant species from Garo Hills were Hoya lanceolata Hook, Nephenthes khasiana Griff, Stellaria repens Pers, Scadoxus multiflora Raf, Nephelaphyllum pulchrum B1., Begonia Roxburghii Roxb, Paphiopedlum venustrum Wall, Hedychium gardenerium Rose, Eriocoulon orchinedes Wall, Drosera rotundifolia L, Kaempferia pulchra Ridl, Frinum cpitatum Br., Calanthe sylvatica Lindl, Curcuma picta Roxb, Alocasia furnicata Schoot., Curcuma zedoaria Christm., Curcuma montana Roxb.

Table 1: Rare and Endangered plant species of Garo Hills, Meghalaya

\begin{tabular}{|l|l|l|l|l|}
\hline S.No & \multicolumn{1}{|c|}{ Botanical Name } & \multicolumn{1}{c|}{ Family } & \multicolumn{1}{c|}{ Habit } & \multicolumn{1}{c|}{ Cause of Threat } \\
\hline 1 & Alocasia furnicata Schoot. & Araceae & Herb & $\begin{array}{l}\text { Habitat loss, Road construction, } \\
\text { over-exploitation }\end{array}$ \\
\hline 2 & Begonia Roxburghii Roxb. & Begoniaceae & Herb & Exploitation for ornamental purpose \\
\hline 3 & Calanthe sylvatica Lindl. & Orchidaceae & $\begin{array}{l}\text { Terrestrial } \\
\text { Herb }\end{array}$ & Exploitation for ornamental purpose \\
\hline 4 & Curcuma montana Roxb. & Zingiberaceae & Herb & Habitat loss \\
\hline 5 & Curcuma picta Roxb, & Zingiberaceae & Herb & Habitat loss \\
\hline
\end{tabular}




\begin{tabular}{|l|l|l|l|l|}
\hline 6 & Curcuma zedoaria Christm. & Zingiberaceae & Herb & Habitat loss \\
\hline 7 & Drosera rotundifolia L. & Droseraceae & Herb & Exploitation for ornamental purpose \\
\hline 8 & Eriocoulon orchinedes Wall. & Erioculaceae & Herb & Exploitation for ornamental purpose \\
\hline 9 & Phrynium capitatum Br. & Zingiberaceae & Herb & Deforestation \\
\hline 10 & Hedychium gardnerianum Rose. & Zingiberaceae & Shrub & Deforestation \\
\hline 11 & Hoya lanceolata Hook. & Asclepiadaceae & Creeper & Exploitation for ornamental purpose \\
\hline 12 & Kaempferia pulchra Ridl. & Zingiberaceae & Herb & Deforestation \\
\hline 13 & Nephelaphyllum pulchrum Bl. & Orchidaceae & $\begin{array}{l}\text { Terrestrial } \\
\text { Herb }\end{array}$ & $\begin{array}{l}\text { Heavy exploitation in the past for } \\
\text { ornamental purposes }\end{array}$ \\
\hline 14 & Nephenthes khasiana Griff. & Nephantaceae & Creeper & Exploitation for ornamental purpose \\
\hline 15 & Paphiopedlum venustrum Wall. & Orchidaceae & $\begin{array}{l}\text { Terrestrial } \\
\text { Herb }\end{array}$ & $\begin{array}{l}\text { Heavy exploitation in the past for } \\
\text { ornamental purposes }\end{array}$ \\
\hline 16 & $\begin{array}{l}\text { Scadoxus multiflora } \text { Raf. } \\
\text { Stellaria repens } \text { Pers. }\end{array}$ & Amaryllidaceae & Herb & Exploitation for ornamental purpose \\
\hline
\end{tabular}

Table 2: Status of endangered ornamental flora of Garo Hills, Meghalaya

\begin{tabular}{|l|l|l|l|}
\hline S.No & \multicolumn{1}{|c|}{ Botanical Name } & \multicolumn{1}{|c|}{ Family } & \multicolumn{1}{|c|}{ Status } \\
\hline 1 & Alocasia furnicata Schoot. & Araceae & Rare \\
\hline 2 & Begonia Roxburghii Roxb. & Begoniaceae & Rare \\
\hline 3 & Calanthe sylvatica Lindl. & Orchidaceae & Rare \\
\hline 4 & Curcuma montana Roxb. & Zingiberaceae & Rare \\
\hline 5 & Curcuma picta Roxb, & Zingiberaceae & Rare \\
\hline 6 & Curcuma zedoaria Christm. & Zingiberaceae & Rare \\
\hline 7 & Drosera rotundifolia L. & Droseraceae & Endangered \\
\hline 8 & Eriocoulon orchinedes Wall. & Erioculaceae & Rare \\
\hline 9 & Phrynium capitatum Br. & Zingiberaceae & Rare \\
\hline 10 & Hedychium gardnerianum Rose. & Zingiberaceae & Rare \\
\hline
\end{tabular}




\begin{tabular}{|l|l|l|l|}
\hline 11 & Hoya lanceolata Hook. & Asclepiadaceae & Endangered \\
\hline 12 & Kaempferia pulchra Ridl. & Zingiberaceae & Rare \\
\hline 13 & Nephelaphyllum pulchrum Bl. & Orchidaceae & Endangered \\
\hline 14 & Nephenthes khasiana Griff. & Nephantaceae & Rare \\
\hline 15 & Paphiopedlum venustrum Wall. & Orchidaceae & Endangered \\
\hline 16 & Scadoxus multiflora Raf. & Amaryllidaceae & Rare \\
\hline 17 & Stellaria repens Pers. & Carryophyllaceae & Endangered \\
\hline
\end{tabular}
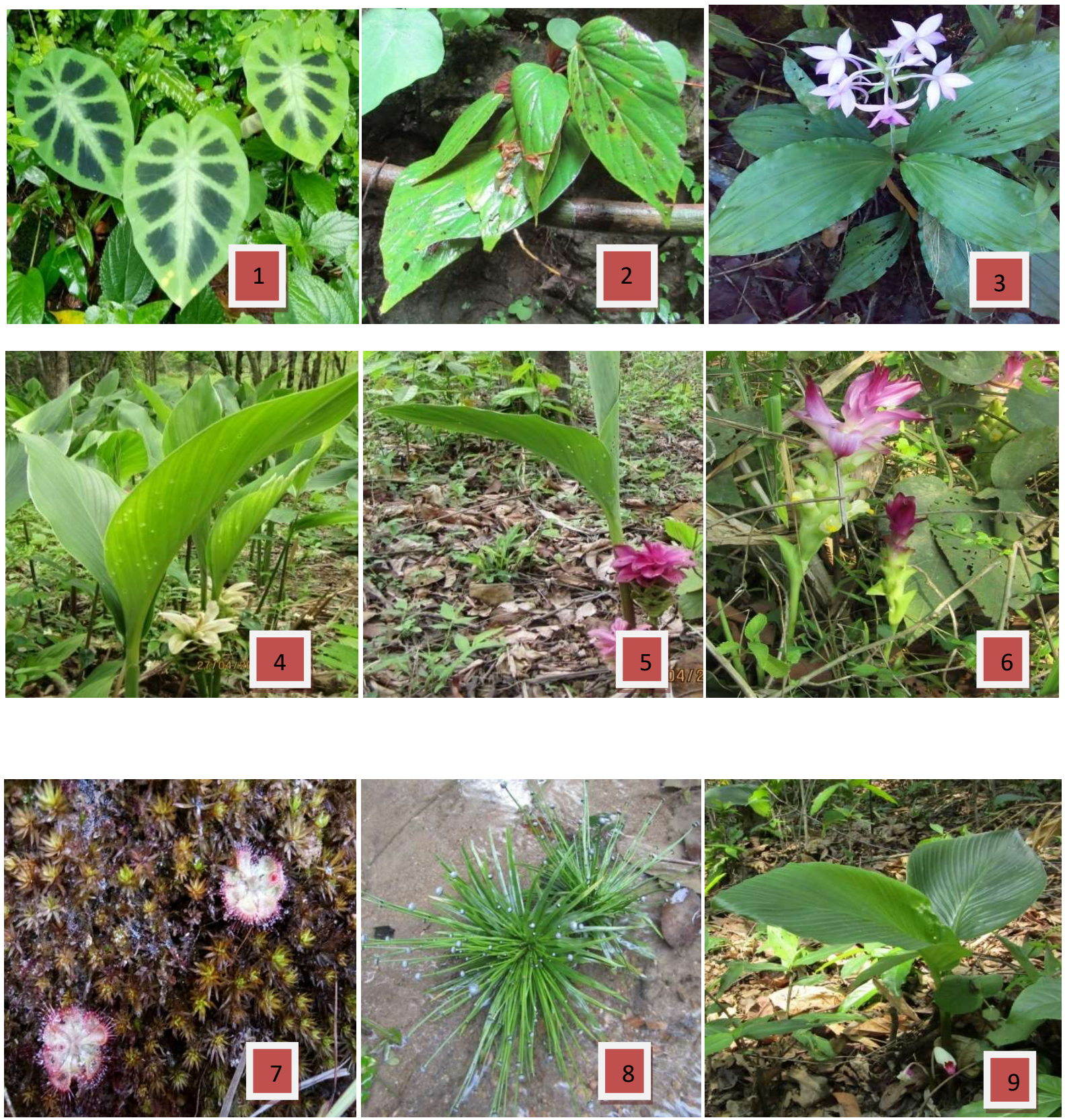

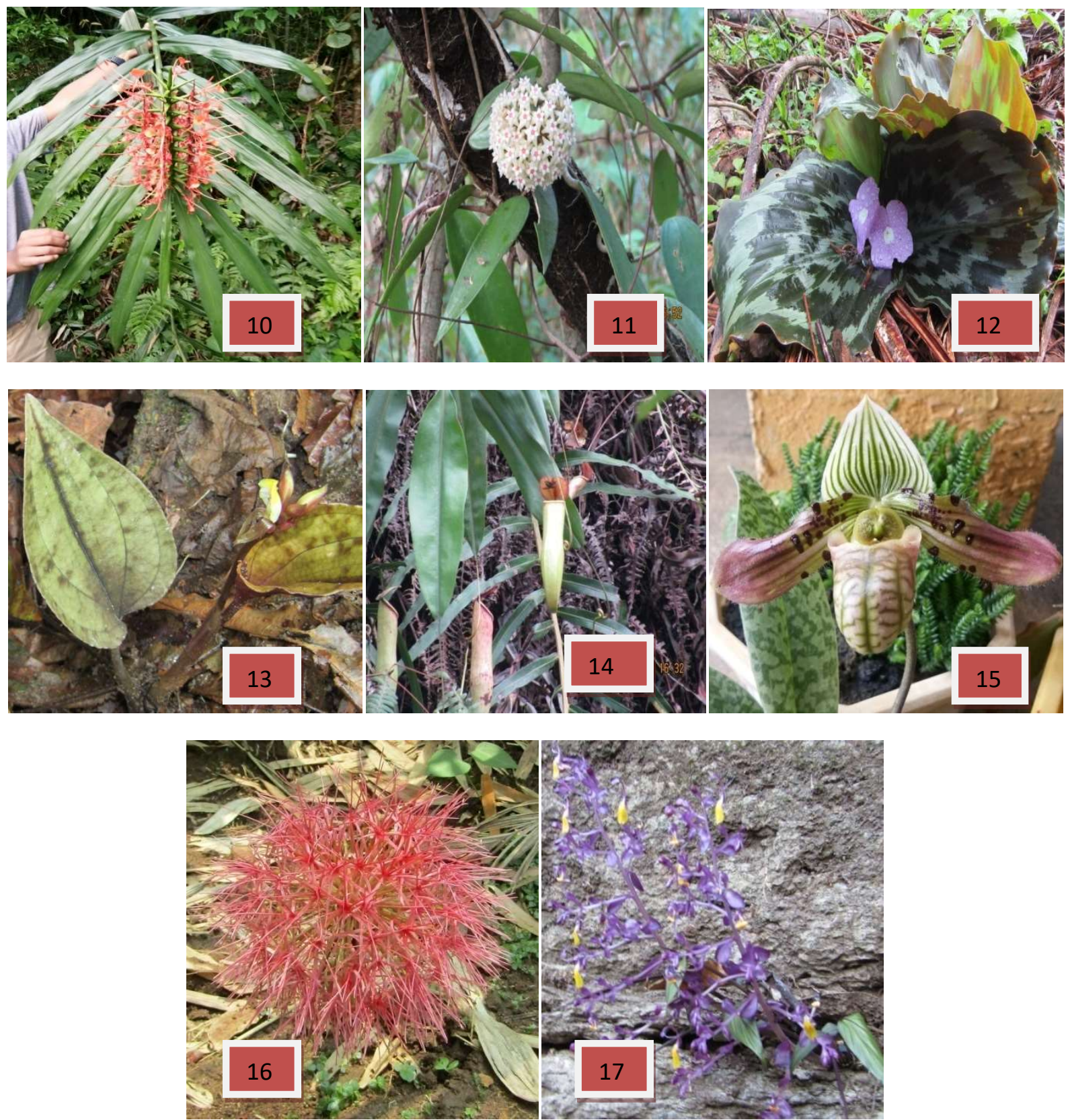

Figure 1: Rare and endangered ornamental plant species of Garo Hills. 1.Alocasia furnicata Schoot. 2.Begonia Roxburghii Roxb. 3.Calanthe sylvatica Lindl. 4.Curcuma montana Roxb. 5.Curcuma picta Roxb. 6.Curcuma zedoaria Christm. 7.Drosera rotundifolia L. 8.Eriocoulon orchinedes Wall. 9. Phrynium capitatum Br. 10. Hedychium gardnerianum Rose. 11.Hoya lanceolata Hook. 12.Kaempferia pulchra Ridl. 13.Nephelaphyllum pulchrum BI. 14. Nephenthes khasiana Griff. 15.Paphiopedlum venustrum Wall. 16.Scadoxus multiflora Raf. 17.Stellaria repens Pers. 


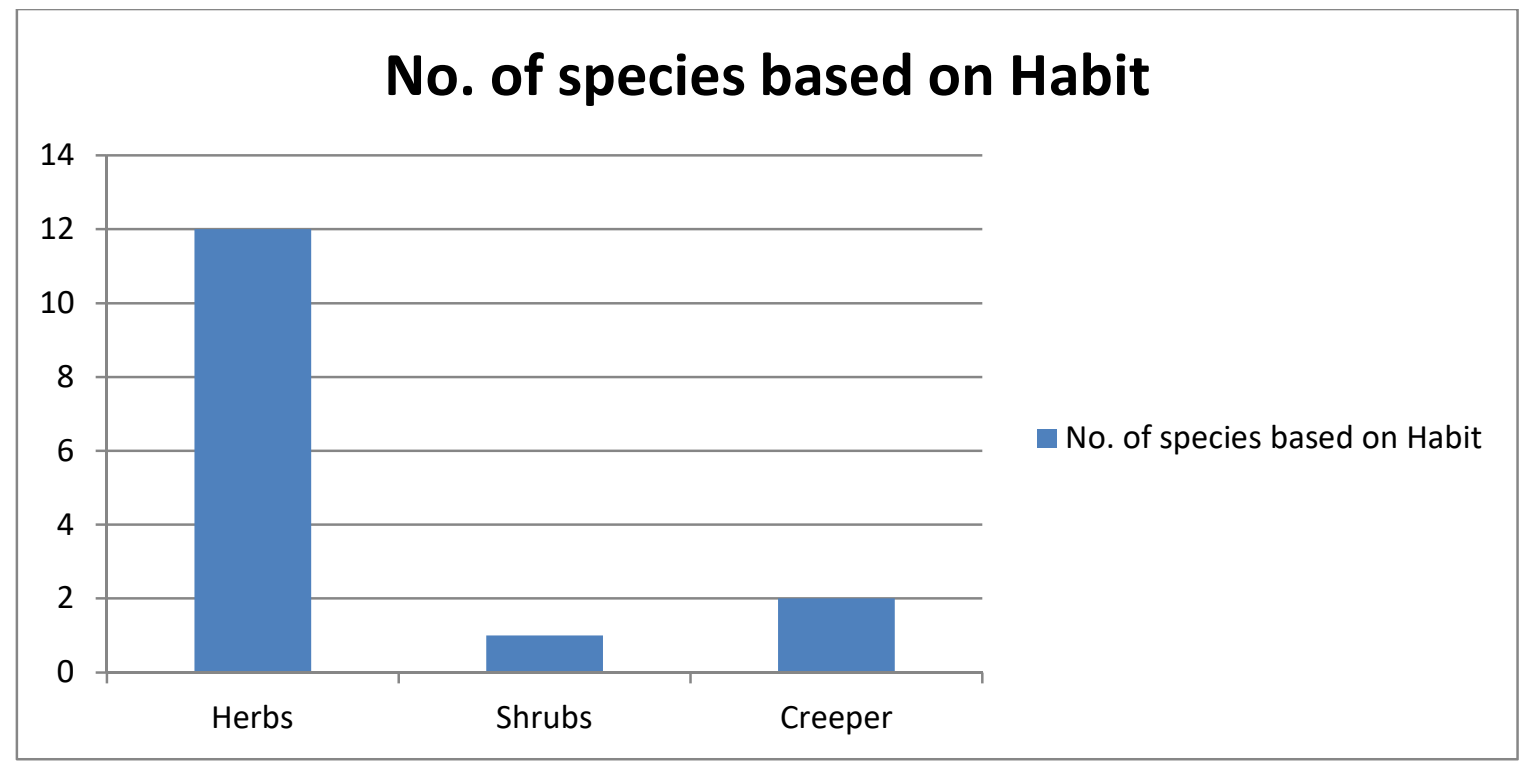

Figure 2: Number of rare and endangered plants based on their habit.

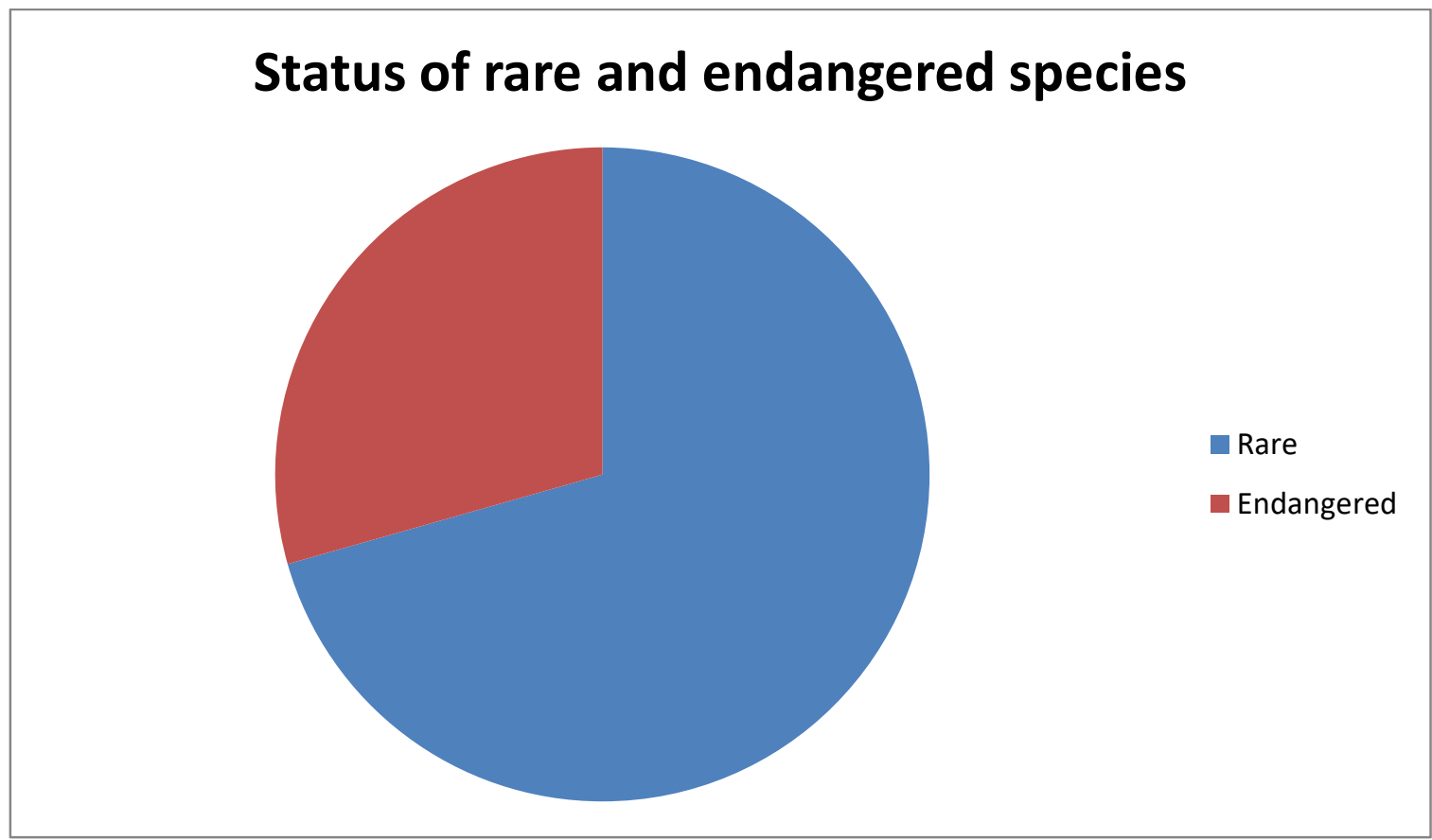

Figure 3: Status of rare and endangered species of Garo Hills.

\section{RESULTS AND DISCUSSIONS}

The results of the present research revealed that there were 17 plant species belonging to 10 families 15 genera (Table 1). Among 17 plant species, 12 species were herbs, 2 species were climbers and 1 species was shrub. Whereas, the highest number of rare and endangered ornamental plant species belonged to the family of Zingiberaceae, having 6 species, followed by Orchidaceae with 3 species. Among the 17 species which were divided into two categories of rare and endangered plant, the 12 plant species were listed in rare and 5 plant species were listed in endangered categories (Table 2). 


\section{CONCLUSIONS}

The increase in population, over exploitation, natural calamities, man-made hazards etc. has become a serious threat to the biodiversity which has caused the wild species to get endangered. These findings will help in identifying the areas and the habitats of the rare and endangered species, so that these species will get priority for conservation. The Government of India as well as NGO's has taken steps in establishing several National parks, sanctuaries and biosphere reserves throughout the country. The in situ and ex situ conservation has also given a tremendous result in protecting the wild rare and endangered species. Public awareness, research and scientific technology will help in conservation of these species in the future. It is the need of an hour that the Government, the NGO's and the community make a joint effort for the best conservation of these species depending on the available resources.

\section{ACKNOWLEDGEMENT}

We are thankful to the Forest officials of Garo hills for providing the essential permit to conduct a successful survey for my research and helping in collection of wild indigenous flora of Orchidaceae and Zingeberaceae family in Garo Hills, Meghalaya.

\section{REFERENCES}

1. Anburaja V, Nandagopalan V, Prakash S, Lakshmi Prabha A. (2012). A report of the threatened plant Decalepis hamiltonii Wight \& Arn. (Asclepiadaceae) from the mid elevation forests of Pachamalai Hills of the Eastern Ghats, Tamil Nadu, Indian Journal of Threatened Taxa, 4(15):3447-3449.

2. Teena Garawal, "Taxus: An Endangered Genus “, International Journal of Agricultural Science and Research (IJASR), Vol. 6, Issue 2, pp.175-178

3. Deshmukh BS.(2010).Ex-Situ Conservation Studies on Ethno- Medicinal Rare, Endemic Plant Species from Western Ghats of Maharashtra. International Journal of Pharma and Bio Sciences. (2):1-6.

4. Gamble, J. S. and C. E. C. Fischer. (1915-1935). Flora of the Presidency of Madras vols 1-3. London. (Rep. ed. 1957. BSI, Calcutta).

5. Joshi, G., L. M. Tewari, N. Lohani, K. Upreti, J. S. Jalal, and G. Tewari. (2009). Diversity of orchids in Uttarakhand and their conservation

6. N. Ramakrishna \& P. Surshbabu, "Ethno-Medico-Botany of Some Sacred Groves of Adilabad District of Telangana State", International Journal of General Medicine and Pharmacy (IJGMP), Vol. 8, Issue 1, pp. 1-8

7. K Aadhan and SP Anand.(2017). Documentation of rare, endanger and threatened medicinal plants species in Sadhuragiri Hills, Tamil Nadu, India. International Journal of Botany Studies. 2(1):32-37

8. Rao C.S. and Singh S.K. (2015). Wild Orchids of Meghalaya-A Pictorial Guide. Meghalaya Biodiversity Board, Shillong.

9. Reddy, C.S., Prachi, U., Murthy, M.S.R. \& Sudhakar, S. (2008). Quantitative structure and composition of tropical forests of Mudumalai Wildlife Sanctuary, Western Ghats, India (Taiwania 53(2): 150-156).

10. Santapau, H. (1973). A Dictionary of the flowering plants in India. Council of Scientific \& Industrial Re-search, New Delhi.

11. Sarvalingam A, Arumugam Rajendran.(2016). Rare, Endangered and Threatened (RET) climbers of Southern Western Ghats, India. Revista Chilena de Historia Natural. 89:1-9. 
12. Manju Deori, “Vascular Hydrophytic Medicinal Plants of Morigaon District, Assam”, BEST: International Journal of Humanities, Arts, Medicine and Sciences (BEST: IJHAMS), Vol. 3, Issue 4, pp. 17-22

13. K. Kalimuthu, T. Sasikala \& R. Prabakaran, "Regeneration of Multiple Shoot from Callus in Boucerosia truncato-coronata (SEDGW) Gravely \& Mayur”, International Journal of Bio-Technology and Research (IJBTR), Vol. 3, Issue 3, pp. 53-60

14. Sirirugsa, P. (1995). The genus Hedychium (Zingiberaceae) in Thailand. Nord. J. Bot. 15:301-304.

15. Vinay Kumar Bharti.(2015). The Rare and Threatened Plants of Shahdol Division Forest of (M.P.) India. International Journal of Applied Research. 1(12):545-548. 